\title{
The effect of purslane hydroextract and zinc on performance, antioxidant capacity and immunity of broiler chickens during summer conditions
}

\author{
Rojin Kazemi, Ardashir Sheikhahmadi, and Ghorbanali Sadeghi \\ Department of Animal Science, Faculty of Agriculture, University of Kurdistan, Sanandaj 66177-15175, Iran \\ Correspondence: Ardashir Sheikhahmadi (a.sheikhahmadi@uok.ac.ir)
}

Received: 13 May 2018 - Revised: 15 August 2018 - Accepted: 20 August 2018 - Published: 11 September 2018

\begin{abstract}
Due to negative effects of high ambient temperature, the present study was conducted to investigate the effects of Portulaca oleracea hydroextract (PHE) and zinc $(\mathrm{Zn})$ on the growth performance and immunity of broiler chickens reared under high summer ambient temperature conditions. A total of 420 day-old male broiler chickens (Ross 308) were randomly allocated to seven dietary treatments each replicated four times with 15 birds per replicate. The basal diet as the control diet was supplemented with $100 \mathrm{mg} \mathrm{kg}^{-1}$ butylated hydroxytoluene (BHT), or 300 and $600 \mathrm{mg} \mathrm{kg}^{-1}$ of PHE, $100 \mathrm{mg} \mathrm{kg}^{-1}$ of zinc and $100 \mathrm{mg} \mathrm{kg}^{-1}$ of zinc plus 300 or $600 \mathrm{mg} \mathrm{kg}^{-1}$ of PHE (ZP300 and ZP600). The result of the present study showed that Zn, PHE and their combination did not alter daily feed intake and feed conversion ratio. Although there was a tendency toward an increase in broiler body weight at 24 and 44 days of age $(P=0.059$ and $P=0.061)$, the body weight of birds fed the basal diet supplemented with $\mathrm{Zn}$ reduced at day 10 . The birds fed diets supplemented with BHT or ZP600 showed lower aspartate aminotransferase (ASAT) and lactate dehydrogenase activity at 24 days of age $(P<0.05)$, but it remains lower in the ZP600 group only for ASAT activity level at day 44 . The results of the present study suggest that dietary PHE and Zn supplementation partially improved body weight and serum antioxidant capacity, superoxide dismutase activity and antibody titer against sheep red blood cells and Newcastle diseases in the broiler chickens during summer conditions.
\end{abstract}

\section{Introduction}

One of the prominent environmental elements influencing broiler performance and health is high ambient temperature (Song et al., 2012; Sun et al., 2015). In most middle eastern countries, the incidences of heat stress commonly happen during the summer conditions and when environmental temperature exceeds the comfort zone of the broiler chickens. In addition to the impairment of feed intake and growth rate, high ambient temperature can cause oxidative stress in farm animals (Mager and Kruijff, 1995; Iwagami, 1996; Lin et al., 2006). Animal cells have an antioxidant defense system which is responsible for protection and/or repair of cell damage caused by reactive oxygen species (ROS). Antioxidant enzymes including superoxide dismutase (SOD), catalase (CAT) and glutathione peroxidase (GSH-Px) play a critical role in neutralizing ROS and protect cells from damage.
Zinc is known as a biologically important trace mineral which acts as a cofactor and activator of more than 300 enzymes in different metabolic pathways (Vallee and Falchuk, 1993; Golding, 2002; Takkar, 2011). Zinc is the cofactor of copper-zinc SOD, as a key enzyme of the antioxidant defense system (Perry et al., 2010). Zinc supplementation (20 to $60 \mathrm{mg} \mathrm{kg}^{-1}$ diet) ameliorated oxidative stress in broiler chickens by increasing the activity of copper-zinc SOD and finally decreased lipid peroxidation (Bun et al., 2011). Furthermore it is reported that the serum malondialdehyde (MDA) concentration, an indicator of lipid peroxidation, decreases with dietary zinc supplementation in heat-stressed quails (Sahin et al., 2006; Kucuk, 2008). Sunder et al. (2008) demonstrated that antibody titers against sheep red blood cells (SRBC) significantly increased in broiler chickens fed diets supplemented with zinc up to $80 \mathrm{mg} \mathrm{kg}^{-1}$. Also, different medicinal herbs, containing antioxidant-rich flavonoids 


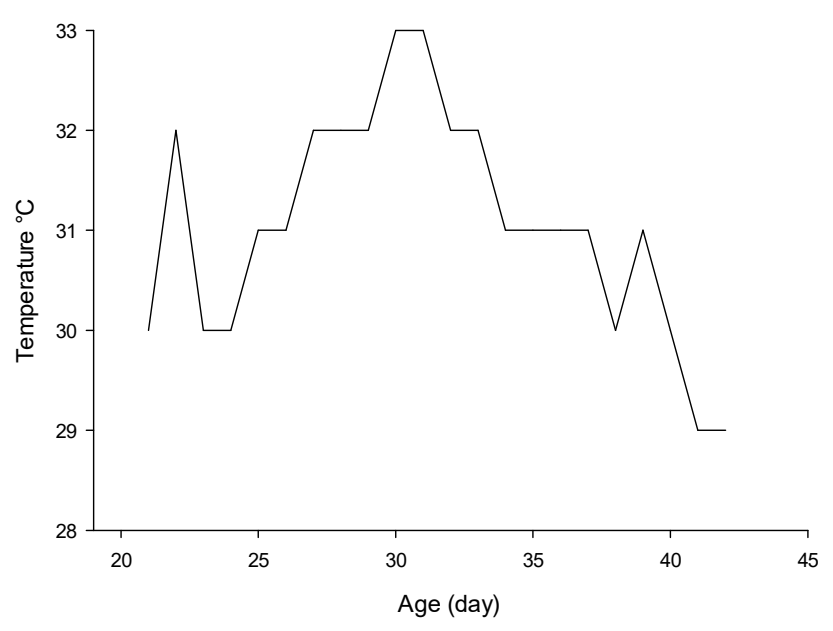

Figure 1. The average daily temperature of the chicken house from 10:00 to 18:00 local time (GMT + 4:30.

and polyphenols, have been receiving much attention as natural antioxidants in the poultry industry. Portulaca oleracea L. (commonly called purslane) is a herbaceous weed rich in antioxidants, including phenolic compounds, $\beta$ carotene, ascorbic acid, tocopherol and glutathione (Xiang et al., 2005; Yang et al., 2009). Dietary supplementation of purslane (extract or powder) in broiler chickens improved their performance and antioxidant status under thermoneutral conditions (Zhao et al., 2013; Sadeghi et al., 2016). To the best of our knowledge, there is no previous research considering a combination of zinc and purslane hydroextract (PHE) on the performance, immune system and antioxidant status of broiler chickens under natural summer high ambient temperature. Although there are dozens of studies conducted on the effect of heat stress in broiler chickens, most of them used artificial heat stress. We hypothesize that the administration of PHE in the diet of broiler chickens during summer alone or in combination with zinc could contribute to improve growth performance, immunity and antioxidant status of broiler chickens. Therefore, the present study was conducted to investigate the effect of PHE (300 and $600 \mathrm{mg} \mathrm{kg}^{-1}$ of diet) and supplemental zinc (100 $\mathrm{mg} \mathrm{kg}^{-1}$ of diet) on the performance, immunity and antioxidant status of broiler chickens under summer high ambient temperature.

\section{Material and methods}

\subsection{Experimental design and purslane extract preparation}

Four hundred and twenty day-old male broiler chickens (Ross 308 ) were randomly allocated to seven dietary treatments each replicated four times with 15 birds per replicate. The basal diet as the control diet was supplemented with $100 \mathrm{mg} \mathrm{kg}^{-1}$ butylated hydroxytoluene (BHT), or 300 and
Table 1. Ingredient composition and analysis of the basal diets.

\begin{tabular}{|c|c|c|c|}
\hline Item (\% unless noted) & Days $0-10$ & $11-24$ & $25-44$ \\
\hline \multicolumn{4}{|l|}{ Ingredients } \\
\hline Corn & 51.14 & 54.58 & 56.01 \\
\hline Soybean meal & 40.33 & 36.45 & 34.04 \\
\hline Soybean oil & 4.19 & 5.04 & 6.28 \\
\hline Dicalcium phosphate & 1.94 & 1.69 & 1.55 \\
\hline Limestone & 1.01 & 0.95 & 0.89 \\
\hline Salt & 0.37 & 0.37 & 0.39 \\
\hline DL-Methionine & 0.22 & 0.19 & 0.17 \\
\hline L-lysine & 0.30 & 0.23 & 0.17 \\
\hline Vitamin and mineral premix & 0.5 & 0.5 & 0.5 \\
\hline \multicolumn{4}{|l|}{ Calculated analysis } \\
\hline Metabolizable energy (ME) $\left(\mathrm{Mcal} \mathrm{kg}^{-1}\right)$ & 3 & 3.1 & 3.2 \\
\hline Crude protein $(\mathrm{CP})$ & 22.5 & 21.0 & 20 \\
\hline Calcium & 0.96 & 0.87 & 0.81 \\
\hline Available phosphorus & 0.48 & 0.43 & 0.40 \\
\hline L-lysine HCL & 1.44 & 1.29 & 1.16 \\
\hline Methionine & 0.56 & 0.51 & 0.47 \\
\hline Calculated $\mathrm{Zn}\left(\mathrm{mg} \mathrm{kg}^{-1}\right)$ & 72.27 & 71.09 & 70.52 \\
\hline Analyzed $\mathrm{Zn}\left(\mathrm{mg} \mathrm{kg}^{-1}\right)$ & 68.62 & 69.10 & 68.24 \\
\hline
\end{tabular}

$600 \mathrm{mg} \mathrm{kg}^{-1}$ of PHE, $100 \mathrm{mg} \mathrm{kg}^{-1}$ of zinc and $100 \mathrm{mg} \mathrm{kg}^{-1}$ of zinc plus 300 or $600 \mathrm{mg} \mathrm{kg}^{-1}$ of PHE (ZP300 and ZP600). The experiment was conducted during July and August 2014. No artificial cooling system was provided to the chickens during the whole experiment period. The average temperature of the poultry house is shown in Fig. 1. Locally harvested whole plants of purslane have been dried (shade dry), powdered and then used for preparing PHE. The antioxidant properties of the PHE have been analyzed and reported previously by Habibian et al. (2017). The content of zinc in the basal diet was determined by a flame atomic absorption spectrophotometer (Phoenix-986, AA spectrophotometer, UK) after wet ashing (Favero et al., 2013).

\subsection{Sample collection}

On 10, 24 and 44 days of age, body weights and feed intake were recorded to calculate daily feed intake (DFI) and feed conversion ratio (FCR). At 24 and 44 days, two birds per replicate were randomly selected, weighted and then a blood sample was drawn from a wing vein by using a syringe within $30 \mathrm{~s}$ and collected in tubes. Serum was obtained after centrifugation (Hettich EBA 21, USA) at $400 \mathrm{~g}$ for $10 \mathrm{~min}$ at $4{ }^{\circ} \mathrm{C}$ and was stored at $-20^{\circ} \mathrm{C}$ for further analysis of triglycerides (TG), aspartate aminotransferase (ASAT), lactate dehydrogenase (LDH), malondialdehyde (MDA), total antioxidant capacity (TAC) and total SOD (T-SOD) activity. On day 44, after blood sampling, the birds were sacrificed and abdominal fat, liver, spleen and bursa of Fabricius were weighted. 


\subsection{Newcastle virus and SRBC antibody response}

At 27 days of age, all the selected chickens were injected in the right wing vein with $1 \mathrm{~mL}$ of $9 \%$ SRBC suspension. Pre-challenge antibody titers were found to be negative. At 7 and 14 days after the first challenge, the birds received a booster injection of $1 \mathrm{~mL} 9 \%$ SRBC. Three days after the last booster injection (on day 44), blood samples were obtained and harvested serums stored at $-20^{\circ} \mathrm{C}$ until assay of the primary antibody response to SRBC. All birds were immunized intramuscularly with a killed vaccine of Newcastle virus at 8 days of age (Clone 30, Nobilis AI + ND). Live Newcastle disease vaccine was administered orally (La Sota strain, Cevac New L) at 18 days of age. At 34 days of age, double blood samples were collected from two birds per replicate. Serum antibody titers against Newcastle virus were determined by a hemagglutination inhibition test and were expressed as the logarithm to base 2 (Allan and Gough, 1974). The experiments were undertaken following the guidelines of the Animal Ethics Committee in Kurdistan University.

\subsection{Serum biochemical and antioxidant parameters}

The concentration of TG and activity of ASAT and LDH in serum were determined by commercial kits (Pars Azmun, Tehran, Iran) using a Jasco V-570 spectrophotometer (Jasco, Tokyo, Japan). The concentrations of MDA and TAC in the serum and T-SOD activity were detected spectroscopically (SHIMADZU UV-1800, Kyoto, Japan) by biochemical methods following the instructions of the corresponding reagent kits (Nanjing Jiancheng Bioengineering Institute of China, Nanjing, China).

\subsection{Statistical analysis}

The experiment was conducted using a completely randomized design. All data were subjected to one-way ANOVA using SAS software (version 8). Duncan's multiple-range analysis was used to compare differences between significant means. Means with $P<0.05$ were considered statistically significant.

\section{Results}

\subsection{Performance}

The effects of supplemental zinc and PHE on the performance parameters of broiler chickens are shown in Table 2. Average body weight of broiler chickens did not significantly alter in zinc and PHE treated groups when compared to the control group at 10 days of age $(P>0.05)$. However, at 24 and 44 days of age, there was a tendency toward an increase in the average body weight of birds fed diets supplemented with zinc and PHE combinations and BHT under summer conditions ( $P=0.059 ; P=0.061)$. No significant alteration in the DFI or FCR was observed when experimental groups were compared with the control group. The treatment effect did not influence mortality ( $P>0.05$, data not shown).

\subsection{Serum biochemical and antioxidant parameters}

As shown in Table 3, none of the dietary treatments resulted in a significant alteration in the serum TG concentrations at 24 and 44 days of age. Although there was a significant $(P<0.05)$ decrease in the ASAT activity in the birds fed $100 \mathrm{mg} \mathrm{kg}^{-1}$ BHT and a combination of $100 \mathrm{mg} \mathrm{kg}^{-1} \mathrm{zinc}$ and $600 \mathrm{mg} \mathrm{kg}^{-1} \mathrm{PHE}$ at 24 days of age. However, at 44 days of age there was no significant reducing effect of BHT, while $600 \mathrm{mg} \mathrm{kg}^{-1}$ of PHE and its combination with $100 \mathrm{mg} \mathrm{kg}^{-1}$ zinc resulted in a significant decrease in the serum ASAT activity $(P<0.05)$. At 44 days of age, $\mathrm{LDH}$ activity of heat-exposed broiler chickens received $100 \mathrm{mg} \mathrm{kg}^{-1}$ BHT, $600 \mathrm{mg} \mathrm{kg}^{-1}$ PHE or $100 \mathrm{mg} \mathrm{kg}^{-1}$ zinc plus $600 \mathrm{mg} \mathrm{kg}^{-1}$ PHE significantly $(P<0.05)$ decreased than those fed control diet.

The effects of supplemental zinc and PHE on the serum antioxidant enzyme activity and MDA concentration in broiler chickens are shown in Table 4. MDA content of serum was reduced in broiler chickens fed $100 \mathrm{mg} \mathrm{kg}^{-1} \mathrm{BHT}$ or $100 \mathrm{mg} \mathrm{kg}^{-1}$ zinc plus $600 \mathrm{mg} \mathrm{kg}^{-1}$ PHE under summer conditions. Moreover, serum MDA concentrations in the birds fed $600 \mathrm{mg} \mathrm{kg}^{-1} \mathrm{PHE}$ in combination with $100 \mathrm{mg} \mathrm{kg}^{-1}$ zinc showed a significant reduction $(P<0.05)$. The results showed that there was a tendency toward reduction in the activity of SOD in the broilers fed diets containing BHT or ZnPHE600 during high ambient temperature exposure $(P=0.050)$.

\subsection{Response to SRBC and Newcastle vaccination}

The effect of dietary treatments of the serum antibody titer against SRBC and Newcastle disease is shown in Table 4 . When compared with the control group, antibody titer against SRBC and Newcastle virus did not improve when birds received diets supplemented with 300 or $100 \mathrm{mg} \mathrm{kg}^{-1}$ supplemental dietary zinc. However, there was a significant increase in the SRBC and broiler chickens fed $600 \mathrm{mg}$ PHE per $\mathrm{kg}$ of diet at 34 days of age $(P<0.05)$.

\section{Discussion}

Positive effects of purslane on the performance of broiler chickens during the growing period have been studied by Zaho et al. (2013) and Ghorbani et al. (2013). However, they reported the effect of purslane powder or PHE in the thermoneutral housing systems. Supplementation of broiler diets with purslane extract improved feed consumption and daily body weight gain in broiler chickens (Zhao et al., 2013; Ghorbani et al., 2014). Lee et al. (2003) suggested that improved digestibility and availability of feedstuff nutrients 
Table 2. Effects of dietary $\mathrm{Zn}$ and PHE on performance of broiler chickens from 1 to 44 days of age. ${ }^{\mathrm{a}-\mathrm{c}}$ indicates that results with the same superscript in each row are not significantly different.

\begin{tabular}{|c|c|c|c|c|c|c|c|c|c|}
\hline \multirow[t]{2}{*}{ Item } & \multicolumn{7}{|c|}{ Treatments } & \multirow[b]{2}{*}{$p$ value } & \multirow[b]{2}{*}{ SEM } \\
\hline & Control & BHT & $\mathrm{Zn}$ & PHE300 & PHE600 & ZPHE300 & ZPHE600 & & \\
\hline \multicolumn{10}{|l|}{ BW (g) } \\
\hline day 10 & $228.50^{\mathrm{abc}}$ & $258.67^{\mathrm{ab}}$ & $211.17^{\mathrm{c}}$ & $240.84^{\mathrm{abc}}$ & $260.59^{\mathrm{a}}$ & $227.00^{\mathrm{bc}}$ & $243.50^{\mathrm{abc}}$ & 0.023 & 4.61 \\
\hline day 24 & 715.44 & 745.73 & 735.31 & 726.76 & 768.59 & 740.90 & 774.36 & 0.059 & 5.92 \\
\hline day 44 & 1985.19 & 2146.71 & 2081.06 & 2121.35 & 1966.06 & 2126.17 & 2216.60 & 0.061 & 24.89 \\
\hline \multicolumn{10}{|c|}{ DFI $\left(\mathrm{g} \mathrm{d}^{-1} \operatorname{bird}^{-1}\right)$} \\
\hline days $01-10$ & $21.59^{\mathrm{abc}}$ & $21.91^{\mathrm{ab}}$ & $19.20^{\mathrm{c}}$ & $23.48^{\mathrm{a}}$ & $23.18^{\mathrm{a}}$ & $20.00^{b c}$ & $21.79^{\mathrm{ab}}$ & 0.012 & 0.38 \\
\hline days $11-24$ & 62.13 & 68.05 & 68.35 & 64.68 & 69.16 & 67.49 & 69.24 & 0.307 & 0.90 \\
\hline days $25-44$ & 152.76 & 166.54 & 157.68 & 146.78 & 164.98 & 145.54 & 164.98 & 0.560 & 3.31 \\
\hline days $01-44$ & 92.74 & 100.84 & 96.39 & 91.30 & 96.76 & 91.35 & 100.09 & 0.511 & 1.55 \\
\hline \multicolumn{10}{|l|}{ FCR $\left(\mathrm{g} \mathrm{g}^{-1}\right)$} \\
\hline days $01-10$ & 1.17 & 1.04 & 1.15 & 1.20 & 1.07 & 1.10 & 1.11 & 0.303 & 0.02 \\
\hline days $11-24$ & 1.78 & 1.96 & 1.82 & 1.93 & 1.84 & 1.91 & 1.77 & 0.597 & 0.03 \\
\hline days $25-44$ & 2.28 & 2.28 & 2.21 & 2.01 & 2.47 & 2.00 & 2.18 & 0.232 & 0.05 \\
\hline days $01-44$ & 2.00 & 2.03 & 1.98 & 1.85 & 2.11 & 1.84 & 1.94 & 0.377 & 0.03 \\
\hline
\end{tabular}

Table 3. Effects of dietary Zn and PHE on the serum level of TG, ASAT and LDH activity in broiler chickens. ${ }^{\mathrm{a}-\mathrm{c}}$ means that results with the same superscript in each row are not significantly different.

\begin{tabular}{lrr|rr|rr}
\hline Item & \multicolumn{2}{c|}{$\mathrm{TG}\left(\mathrm{mg} \mathrm{dL}^{-1}\right)$} & \multicolumn{2}{|c|}{ ASAT $\left(\mathrm{UL}^{-1}\right)$} & \multicolumn{2}{c}{$\mathrm{LDH}\left(\mathrm{UL}^{-1}\right)$} \\
\cline { 2 - 7 } & Days 24 & 44 & 24 & 44 & 24 & 44 \\
\hline Control & 91.70 & 124.92 & $182.42^{\mathrm{ab}}$ & $303.76^{\mathrm{a}}$ & $1938.65^{\mathrm{a}}$ & 1268.24 \\
BHT & 281.61 & 97.47 & $113.46^{\mathrm{c}}$ & $250.70^{\mathrm{ab}}$ & $1220.96^{\mathrm{c}}$ & 1227.63 \\
Zn & 95.86 & 81.28 & $182.21^{\mathrm{ab}}$ & $266.53^{\mathrm{ab}}$ & $1581.58^{\mathrm{abc}}$ & 1070.67 \\
P300 & 84.70 & 112.48 & $154.03^{\mathrm{abc}}$ & $264.22^{\mathrm{ab}}$ & $1531.32^{\mathrm{abc}}$ & 1156.90 \\
P600 & 140.79 & 97.25 & $145.32^{\mathrm{bc}}$ & $242.79^{\mathrm{bc}}$ & $1423.04^{\mathrm{bc}}$ & 1286.34 \\
ZP300 & 111.03 & 89.63 & $196.58^{\mathrm{a}}$ & $279.80^{\mathrm{ab}}$ & $1781.16^{\mathrm{ab}}$ & 1313.66 \\
ZP600 & 109.79 & 119.46 & $122.96^{\mathrm{c}}$ & $193.09^{\mathrm{c}}$ & $1334.87^{\mathrm{c}}$ & 1030.06 \\
SEM & 5.13 & 4.77 & 7.31 & 8.41 & 59.84 & 36.61 \\
$p$ value & 0.327 & 0.084 & 0.026 & 0.042 & 0.043 & 0.333 \\
\hline
\end{tabular}

Abbreviations: BHT, butylated hydroxytoluene; Zn, zinc; PHE300, purslane hydroextract $300 \mathrm{mg} \mathrm{kg}^{-1}$ of diet; PHE600, purslane hydroextract $600 \mathrm{mg} \mathrm{kg}^{-1}$ of diet; ZPHE300, zinc $100 \mathrm{mg} \mathrm{kg}^{-1}$ diet + purslane hydroextract $300 \mathrm{mg} \mathrm{kg}^{-1}$; ZPHE600, zinc $100 \mathrm{mg} \mathrm{kg}^{-1}$ diet + purslane hydroextract $600 \mathrm{mg} \mathrm{kg}^{-1}$ of diet; TG, triglyceride; ASAT, aspartate aminotransferase; LDH, lactate dehydrogenase; SEM, standard error of means; values are means \pm SEM.

could be due to greater digestive enzyme production and/or activity by supplementing broiler diets with purslane.

Heat challenge leads to an increase in free radical production and oxidative damage which subsequently increases LDH and ASAT, reflecting tissue damage (Mikami et al., 2004; Sandercock et al., 2006). In the current study, reduced activity of serum ASAT at 24 and 44 days in birds fed a combination of $100 \mathrm{mg} \mathrm{kg}^{-1}$ zinc and $600 \mathrm{mg} \mathrm{kg}^{-1}$ PHE sug- gests a possible alleviating effect of liver oxidative injuries in broiler chickens during high ambient temperature.

Oxidative damages reflect the imbalance between prooxidant and antioxidant systems. In intact rats, it is demonstrated that high hyperthermic conditions increased formation of ROS in the portal circulation (Hall et al., 1994; Lin et al., 2006). In broiler chickens, high ambient temperature increased plasma MDA which indicated an oxidant/antioxidant equilibrium disturbance leading to oxidative stress (Lin et al., 
Table 4. Effects of dietary $\mathrm{Zn}$ and PHE on the serum concentration of MDA, TAC and T-SOD activity and antibody titers against SRBC and Newcastle virus in broiler chickens.

\begin{tabular}{lrrrrr}
\hline Item & $\begin{array}{r}\text { MDA } \\
\left(\mathrm{nmol} \mathrm{mL}^{-1}\right)\end{array}$ & $\begin{array}{r}\text { TAC } \\
\left(\mathrm{mmol}^{-1}\right)\end{array}$ & $\begin{array}{r}\text { T-SOD } \\
\left(\mathrm{U} \mathrm{mL}^{-1}\right)\end{array}$ & SRBC & $\begin{array}{r}\text { Newcastle } \\
\text { titer }\end{array}$ \\
\hline Control & $2.02^{\mathrm{a}}$ & $0.79^{\mathrm{c}}$ & 142.71 & $3.37^{\mathrm{c}}$ & $3.16^{\mathrm{c}}$ \\
BHT & $1.38^{\mathrm{b}}$ & $1.16^{\mathrm{a}}$ & 106.51 & $2.62^{\mathrm{c}}$ & $3.14^{\mathrm{c}}$ \\
Zn & $2.02^{\mathrm{a}}$ & $0.95^{\mathrm{abc}}$ & 138.20 & $2.62^{\mathrm{c}}$ & $3.08^{\mathrm{c}}$ \\
P300 & $2.01^{\mathrm{a}}$ & $0.90^{\mathrm{bc}}$ & 129.77 & $3.50^{\mathrm{c}}$ & $3.70^{\mathrm{bc}}$ \\
P600 & $1.78^{\mathrm{ab}}$ & $1.13^{\mathrm{a}}$ & 118.21 & $5.50^{\mathrm{a}}$ & $5.53^{\mathrm{a}}$ \\
ZP300 & $1.76^{\mathrm{ab}}$ & $1.03^{\mathrm{ab}}$ & 130.16 & $3.50^{\mathrm{c}}$ & $4.12^{\mathrm{abc}}$ \\
ZP600 & $1.48^{\mathrm{b}}$ & $1.16^{\mathrm{a}}$ & 109.76 & $4.37^{\mathrm{b}}$ & $4.92^{\mathrm{ab}}$ \\
SEM & 0.06 & 0.03 & 3.76 & 0.17 & 0.23 \\
$p$ value & 0.031 & 0.004 & 0.050 & $<0.0001$ & 0.010 \\
\hline
\end{tabular}

Abbreviations: BHT, butylated hydroxytoluene; Zn, zinc; PHE300, purslane hydroextract $300 \mathrm{mg} \mathrm{kg}^{-1}$ of diet; PHE600, purslane hydroextract $600 \mathrm{mg} \mathrm{kg}^{-1}$ of diet; ZPHE300, zinc $100 \mathrm{mg} \mathrm{kg}^{-1}$ diet + purslane hydroextract $300 \mathrm{mg} \mathrm{kg}^{-1}$ of diet; ZPHE600, zinc $100 \mathrm{mg} \mathrm{kg}^{-1}$ diet + purslane hydroextract $600 \mathrm{mg} \mathrm{kg}^{-1}$ of diet; MDA, malondialdehyde; TAC, total antioxidant capacity; CAT, catalase; SRBC, sheep red blood cells; HA, hemagglutination assay; SEM, standard error of means; values are means \pm SEM. ${ }^{\mathrm{a}-\mathrm{c}}$ means that results with the same superscript in each row are not significantly different.

2000, 2006; Yang et al., 2010). In our present study, supplemented basal diet with $100 \mathrm{mg} \mathrm{kg}^{-1}$ BHT or $100 \mathrm{mg} \mathrm{kg}^{-1}$ zinc plus $600 \mathrm{mg} \mathrm{kg}^{-1}$ PHE significantly decreased the content of serum MDA in broiler chickens reared under summer conditions. As a consequence of high ambient temperature, increased ROS production led to increased lipid peroxidation that was indicated by the concentration of MDA. Therefore, the content of MDA in serum can be used as an indirect index of lipid peroxidation and overproduction of ROS (Yang et al., 2010). This effect could be due to increased antioxidant capacity of the birds. As the results showed, the level of serum TAC increased in the BHT and ZnP600 groups. Purslane is known as an important source of biologically active components with high antioxidant activity (Youssef and Mokhtar, 2014). Although the PHE we used in the present study showed a high total phenolic content and 1,1-diphenyl2-picrylhydrazyl (DPPH) radical-scavenging activity, none of the groups that were fed supplemented diets with 300 or $600 \mathrm{mg} \mathrm{kg}^{-1}$ of PHE showed a reduction in the serum MDA. It is strongly possible that higher levels of PHE are needed to improve broiler chickens antioxidant capacity during high ambient temperature condition. Interestingly, there was a reduction in serum MDA concentration in the birds fed $600 \mathrm{mg} \mathrm{kg}^{-1}$ PHE in combination with $100 \mathrm{mg} \mathrm{kg}^{-1} \mathrm{Zn}$. It has been well discussed that $\mathrm{Zn}$ is able to exert antioxidant effects by inducing the expression of metallothioneins, as potent electrophilic scavengers and cytoprotective agents and activation of antioxidant proteins and enzymes, such as glutathione and catalase (Jarosez et al., 2017). Hence it is likely that a combination of $100 \mathrm{mg} \mathrm{kg}^{-1}$ zinc and $600 \mathrm{mg} \mathrm{kg}^{-1}$ PHE resulted in a synergistic effect and reduced MDA production.

One of the important enzymes that can protect animals from oxidative injury is SOD, which clears superoxide an- ions. It is reported that a small increase in ROS can induce the expression of SOD (McArdle and Jackson, 2000). Consequently, SOD activity and MDA concentration are commonly combined when investigating the effect of antioxidant feed additives. In our present study, the activity of SOD tended to be decreased in the broilers fed diets supplemented with BHT or ZnP600 during high ambient temperature exposure. BHT is known as a strong antioxidant and therefore in the present study it is strongly possible that due to its ability to neutralize ROS, dietary BHT supplementation led to lower activity of T-SOD in the serum of broiler chickens. Although there is no previous report on the possible effect of BHT (synthetic antioxidant) on SOD activity, previous studies reported that vitamin $\mathrm{E}$ (natural antioxidant) supplementation decreases TSOD activity (Mantha et al., 1993; Muller and Pallauf, 2003; Song et al., 2017).

It is well known that antibody responses decreased in the birds reared under high ambient temperature conditions (Donker et al., 1990; Bartlett and Smith 2003; Mahmoud and Edens, 2003). Under stress conditions, increased inflammatory cytokine production (Ogle et al., 1997) stimulates corticotrophin-releasing factor from the hypothalamus ending with release of corticosterone and finally inhibits antibody production (Gross, 1992). In the present study antibody titers against Newcastle virus increased in broiler chickens fed $600 \mathrm{mg}$ PHE per $\mathrm{kg}$ of diet at 34 days of age. Some previous studies showed that dietary vitamins $E$ and $C$, as natural antioxidants, significantly increased antibody response to SRBC in the broiler (Singh et al., 2008) and layers (Panda et al., 2008) under high ambient temperature. Antibody response against SRBC, as an indicator for routine evaluation of humoral immunity, involves both $\mathrm{B}$ and $\mathrm{T}$ lymphocytes and are used in immunological studies (Hõrak et al., 2003). Oxidative stress directly induces immune system damage 
(Biller-Takahashi et al., 2015; Marri and Richner, 2015). Hence it is likely that high ambient temperature initiated oxidative stress resulting in lower antibody titer against SRBC and Newcastle virus; however, supplemented broiler diets with $600 \mathrm{mg} \mathrm{kg}^{-1}$ of PHE enhanced serum antibody. Positive effect of antioxidants on the humoral immune system response has been previously reported; however, physiological mechanisms need to be further elucidated.

\section{Conclusions}

1. Inclusion of $600 \mathrm{mg} \mathrm{kg}^{-1}$ of supplemental PHE and also a combination of PHE and zinc ( $100 \mathrm{mg} \mathrm{kg}^{-1}$ basal diet) partially improved the body weight of broiler chickens reared under summer high ambient temperature conditions.

2. Dietary supplementation of $600 \mathrm{mg}$ PHE per kilogram of diet could be advisable to be used in broiler chickens during summer conditions to improve their antioxidant capacity and immune response against Newcastle virus.

Data availability. The original data of the paper are available upon request from the corresponding author.

Author contributions. RK performed this experiment and provided data. AS designed this experiment, analyzed the data and wrote the paper; GS designed the experiment, edited the paper and gave advice.

Competing interests. The authors declare that they have no conflict of interest.

Acknowledgements. This work was funded by the University of Kurdistan grant. We would like to address special thanks to Mahmood Habibian for his help and advice with the purslane extract process. Moreover, thanks to Keyvan Sobhani for his kind assistance with SRBC and Newcastle disease test measurements.

Edited by: Manfred Mielenz

Reviewed by: Soudabeh Moradi and one anonymous referee

\section{References}

Allan, W. H. and Gough, R. E.: A standard haemagglutination inhibition test for Newcastle disease (1), A comparison of macro and micro methods, Vet. Rec., 95, 120-123, 1974.

Bartlett, J. R. and Smith, M. O.: Effects of different levels of zinc on the performance and immunocompetence of broilers under heat stress, Poult. Sci., 82, 1580-1588, 2003.

Biller-Takahashi, J. D., Takahashi, L. S., Mingatto, F. E., and Urbinati, E. C.: The immune system is limited by oxidative stress: Dietary selenium promotes optimal antioxidative status and greatest immune defense in pacu Piaractus mesopotamicus, Fish. Shellfish. Immunol., 47, 360-367, 2015.

Bun, S. D., Guo, Y. M., Guo, F. C., Ji, F. J., and Cao, H.: Influence of organic zinc supplementation on the antioxidant status and immune responses of broilers challenged with Eimeria tenella, Poult. Sci., 90, 1220-1226, 2011.

Donker, R. A., Nieuwland, M. G. B., and van der Zijpp, A. J.: Heatstress influences on antibody production in chicken lines selected for high and low immune responsiveness, Poult. Sci., 69, 599607, 1990.

Favero, A., Vieira, S. L., Angel, C. R., Bos-Mikich, A., Lothhammer, N., Taschetto, D., Cruz, R. F. A., and Ward, T. L.: Development of bone in chick embryos from Cobb 500 breeder hens fed diets supplemented with zinc, manganese, and copper from inorganic and amino acid-complexed sources, Poult. Sci., 92, 402411, 2013.

Ghorbani, M. R., Bojarpur, M., Mayahi, M., Fayazi, J., Fatemitabatabaei, R. and Tabatabaei, S.: Effect of purslane (Portulaca oleracea $\mathrm{L}$.) on blood lipid concentration and antioxidant status of broiler chickens, Online J. Vet. Res., 17, 54-63, 2013.

Ghorbani, M. R., Bojarpur, M., Mayahi, M., Fayazi, J., Fatemitabatabaei, R., Tabatabaei, S., and Zulkifli, I.: Effects of purslane extract on performance, immunity responses and cecal microbial population of broiler chickens, Span. J. Agr. Res., 12, 1094 1098, 2014.

Golding, G.: Zinc: A mini review, J. Aust. Tradit. Med. Soc., 8, 65$68,2002$.

Gross, W. B.: Effect of short-term exposure of chickens to corticosterone on resistance to challenge exposure with Escherichia coli and antibody response to sheep erythrocytes, Am. J. Vet. Res., 53, 291-293, 1992.

Habibian, M., Sadeghi, G. H., and Karimi, A.: Comparative effects of powder, aqueous, and methanolic extracts of purslane (Portulaca oleracea L.) on growth performance, antioxidant status, abdominal fat deposition, and plasma lipids in broiler chickens, Anim. Prod. Sci., https://doi.org/10.1071/AN17352, 2017.

Hall, D. M., Buettner, G. R., Matthes, R. D., and Gisolfi, C. V.: Hyperthermia stimulates nitric oxide formation: electron paramagnetic resonance detection of NO-heme in blood, J. Appl. Physiol., 77, 548-553, 1994.

Hõrak, P., Saks, L., Ots, I., Kullisaar, T., Kollist, H., and Zilmer, M.: Physiological effects of immune challenge in captive greenfinches (Carduelis chloris), Can. J. Zool., 81, 371-379, 2003.

Iwagami, Y.: Changes in the ultrasonic of human cells related to certain biological responses under hyperthermic culture conditions, Hum. Cell., 9, 353-366, 1996.

Jarosz, M., Olbert, M., Wyszogrodzka, G., Młyniec, K., and Librowski, T.: Antioxidant and anti inflammatory effects of zinc. Zinc-dependent NF- $\kappa$ B signaling, Inflammopharmacology, 25, 11-24, 2017.

Kucuk, O.: Zinc in a combination with magnesium helps reducing negative effects of heat stress in quails, Biol. Trace Elem. Res., 123, 144-153, 2008.

Lee, K. W., Everts, H., Kappert, H. J., Frehner, M., Losa, R., and Beyen, A. C.: Effects of dietary essential oil components on growth performance, digestive enzymes and lipid metabolism in female broiler chickens, Br. Poult. Sci., 44, 450-457, 2003. 
Lin, H., Du, R., and Zhang, Z. Y.: The peroxidation in tissues of heat-stress broilers. Asian-Austral, J. Anim. Sci., 13, 13731376, 2000.

Lin, H., Decuypere, E., and Buyse, J.: Acute heat stress induces oxidative stress in broiler chickens, Comp. Biochem. Physiol. A. Mol. Integr. Physiol., 144, 11-17, 2006.

Mager, W. H. and De Kruijff, A. J.: Stress-induced transcriptional activation, Microbiol. Rev., 59, 506-531, 1995.

Mahmoud, K. Z. and Edens, F. W.: Influence of selenium sources on agerelated and mild heat stress-related changes of blood and liver glutathione redox cycle in broiler chickens (Gallus domesticus), Comp. Biochem. Physiol. B., 136, 921-934, 2003.

Mantha, S. V., Prasad, M., Kalra, J., and Prasad, K.: Antioxidant enzymes in hypercholesterolemia and effects of vitamin $\mathrm{E}$ in rabbits, Atherosclerosis, 101, 135-144, 1993.

Marri, V. and Richner, H.: Immune response, oxidative stress and dietary antioxidants in great tit nestlings, Comp. Biochem. Physiol. A. Mol. Integr. Physiol., 179, 192-196, 2015

McArdle, A. and Jackson, M. J.: Exercise, oxidative stress and ageing, J. Anat., 197, 539-541, 2000.

Mikami, T., Sumida, S., Ishibashi, Y., and Ohta, S.: Endurance exercise training inhibits activity of plasma GOT and liver caspase-3 of mice (correction of rats) exposed to stress by induction of heat shock protein 70, J. Appl. Physiol., 96, 1776-1781, 2004.

Muller, A. S. and Pallauf, J.: Effect of increasing selenite concentrations, vitamin E supplementation and different fetal calf serum content on GPx1 activity in primary cultured rabbit hepatocytes, J. Trace. Elem. Med. Biol., 17, 183-192, 2003.

Niu, Z. Y., Liu, F. Z., Yan, Q. L., and Li, W. C.: Effects of different levels of vitamin $\mathrm{E}$ on growth performance and immune responses of broilers under heat stress, Poult. Sci., 88, 2101-2107, 2009.

Ogle, C. K., Valente, J. F., Guo, X., Li, B. G., Ogle, J. D., and Alexander J. W.: Thermal injury induces the development of inflammatory macrophages from nonadherent bone marrow cells, Inflammation, 21, 569-582, 1997.

Panda, A. K., Ramarao, S. V., Raju, M. V., and Chatterjee, R. N.: Effect of dietary supplementation with vitamins $\mathrm{E}$ and $\mathrm{C}$ on production performance, immune responses and antioxidant status of White Leghorn layers under tropical summer conditions, $\mathrm{Br}$. Poult. Sci., 49, 592-599, 2008.

Perry, J. J. P., Shin, D. S., Getzoff, E. D., and Tainer, J. A.: The structural biochemistry of the superoxide dismutases, Biochim. Biophys. Acta., 1804, 245-262, 2010.

Sadeghi, G. H., Karimi, A., Shafeie, F., Vaziry, A., and Farhadi, D.: The Effects of purslane (Portulaca oleracea L.) powder on growth performance, carcass characteristics, antioxidant status, and blood metabolites in broiler chickens, Livest. Sci., 184, 3540, 2016.
Sahin, K., Onderci, M., Sahin, N., Balci, T. A., Gursu, M. F., Juturu, V., and Kucuk, O.: Dietary arginine silicate inositol complex improves bone mineralization in quail, Poult. Sci, 85, 486492, 2006.

Sandercock, D. A., Hunter R. R., and Mitchell M. A.: Thermoregulatory capacity and muscle membrane integrity are compromised in broilers compared with layers at the same age or body weight, edited by: Hocking P. M., Br. Poult. Sci, 47, 322-329, 2006.

Singh, H., Sodhi, S., and Kaur, R.: Effects of dietary supplements of selenium, vitamin $\mathrm{E}$ or combinations of the two on antibody response of broilers, Br. Poult. Sci., 47, 714-719, 2006.

Song, Z., Liu, L., Sheikhahmadi, A., Jiao, H., and Lin, H.: Effect of Heat Exposure on Gene Expression of Feed Intake Regulatory Peptides in Laying Hens, J. Biom. Biotech., 8, 484869, https://doi.org/10.1155/2012/484869, 2012.

Song, Z., Lv, J., Sheikhahmadi, A., Uerlings, J., and Everaert, N.: Attenuating Effect of Zinc and Vitamin E on the Intestinal Oxidative Stress Induced by Silver Nanoparticles in Broiler Chickens, Biol. Trace. Elem. Res., 180, 306-313, 2017.

Sun, X., Zhang, H., Sheikhahmadi, A., Wang, Y., Jiao, H., Lin, H., and Song, Z.: Effects of heat stress on the gene expression of nutrient transporters in the jejunum of broiler chickens (Gallus gallus domesticus), Int. J. Biometeorol., 59, 127-135, 2015.

Sunder, G. S., Panda, A., Gopinath, N., Rao, S. R., Raju, M., Reddy, M., and Kumar, C. V.: Effects of higher levels of zinc supplementation on performance, mineral availability, and immune competence in broiler chickens, J. Appl. Poult. Res., 17, 79-86, 2008.

Takkar, P. N.: Zinc in human and animal health, Indian J. Fert., 7, 46-66, 2011.

Vallee, B. L. and Falchuk, K. H.: The biochemical basis of zinc physiology, Physiol. Rev., 73, 79-118, 1993.

Xiang, L., Xing, D., Wang, W., Wang, R., Ding, Y., and Du, L.: Alkaloids from Portulaca oleracea L., Phytochemistry, 66, 25952601, 2005.

Yang, L., Tan, G. Y., Fu, Y. Q., Feng, J. H., and Zhang, M. H.: Effects of acute heat stress and subsequent stress removal on function of hepatic mitochondrial respiration, ROS production and lipid peroxidation in broiler chickens, Comp. Biochem. Physiol. C. Toxicol. Pharmacol., 151, 204-208, 2010.

Yang, Z., Liu, C., Xiang, L., and Zheng, Y.: Phenolic alkaloids as a new class of antioxidants in Portulaca oleracea, Phytother. Res., 23, 1032-1035, 2009.

Youssef, K. M. and Mokhtar, S. M.: Effect of Drying Methods on the Antioxidant Capacity, Color and Phytochemicals of Portulaca oleracea L. Leaves, J. Nutr. Food. Sci., 4, 322, https://doi.org/10.4172/2155-9600.1000322, 2014.

Zhao, X. H., He, H., Yang, X. F., and Zhong, X. H.: Effect of Portulaca oleracea extracts on growth performance and microbial populations in ceca of broilers, Poult. Sci., 92, 1343-1347, 2013. 